\title{
After-ripening, Light Conditions, and Cold Stratification Influence Germination of Marula [Sclerocarya birrea (A. Rich.) Hochst. subsp. caffra (Sond.) Kokwaro] Seeds
}

\author{
Mack Moyo, Manoj G. Kulkarni, Jeffrey F. Finnie, and \\ Johannes Van Staden ${ }^{1}$ \\ Research Centre for Plant Growth and Development, School of Biological \\ and Conservation Sciences, University of KwaZulu-Natal, Pietermaritzburg, \\ Private Bag X01, Scottsville 3209, South Africa
}

Additional index words. seed storage, photoinhibition, light intensity

\begin{abstract}
Marula [Sclerocarya birrea (A. Rich.) Hochst. subsp. caffra (Sond.) Kokwaro (Anacardiaceae)] is used in many African countries as a food crop and is also in demand for industrial purposes. The fruit pulp has high vitamin $C$ levels and the nuts have a high protein and oil content. The fruit pulp is commercially used in the production of an alcoholic beverage (Amarula Cream) and the oil is gaining importance in the cosmetic industry. Although attempts are being made to domesticate this high-value indigenous tree, there is very limited information available on aspects of seed germination. Our study investigated the role of light, temperature, cold stratification, and after-ripening on seed germination of $S$. birrea. Temperatures between 25 and $35^{\circ} \mathrm{C}$ favored germination of opercula-removed seeds under continuous dark conditions. White light completely inhibited seed germination with the inhibitory effect being reversed when seeds were transferred to dark conditions. This photoinhibitory effect on opercula-removed seeds was lost after 12 months of seed storage at room temperature in the dark. Cold stratification $\left(5^{\circ} \mathrm{C}\right)$ of intact seeds for 14 days significantly improved germination $(65 \%)$ as compared with nonstratified seeds $(32 \%)$. Pregermination treatments (acid scarification, boiling water, dry heat, soaking, and plant growth regulators) of $S$. birrea seeds did not promote germination. Seeds of $S$. birrea can be considered orthodox because they tolerated desiccation without significant loss of viability. Both intact and opercularemoved seeds readily imbibe water suggesting physiological rather than physical dormancy. The highest germination percentage was recorded under constant dark conditions at $25^{\circ} \mathrm{C}$ for opercula-removed seeds exposed to an after-ripening period of 12 months. This study indicates that after-ripening, light conditions, and cold stratification are critical factors for germination of $S$. birrea seeds.
\end{abstract}

Sclerocarya birrea is native to the semiarid deciduous savannas of sub-Saharan Africa (Muok et al., 2007) and is one of the most highly valued indigenous trees in southern Africa (Von Teichman and Robbertse, 1986). Besides a number of medicinal uses (Eloff, 2001), the importance of $S$. birrea is underpinned by its diverse characteristics such as high levels of vitamin $\mathrm{C}$ and protein, quality stable oil, and the novel flavor of its fruit. The vitamin C content of $S$. birrea fruit juice is approximately four to five times more than the levels found in the average orange juice (Jaenicke and Thiong'o, 2000; Mojeremane and Tshwenyane, 2004). Bio-

\footnotetext{
Received for publication 18 Sept. 2008. Accepted for publication 25 Sept. 2008.

The National Research Foundation (NRF), Pretoria and the University of KwaZulu-Natal are thanked for financial support.

${ }^{1}$ To whom reprint requests should be addressed; e-mail rcpgd@ukzn.ac.za
}

chemical analyses indicate that the kernels have higher protein and oil content than most of the popular nuts, including walnuts, hazelnuts, chestnuts, and almonds (Wynberg et al., 2003).

Humankind has benefitted from $S$. birrea as a source of nutrition for more than 10,000 years (Nwonwu, 2006). Apart from contributing to rural diets, the fruit is used to brew an alcoholic beverage with an annual gross value of $\approx \$ 80$ to $\$ 100$ U.S. per household (Emanuel et al., 2005; Shackleton et al., 2008). The oil is in high demand in the pharmaceutical and cosmetic industries (Kleiman et al., 2008; Nwonwu, 2006), whereas the nuts are used in the food industry for making a range of products, including chocolates. With the realization of its market value, there is notable growth in the trade of $S$. birrea products stimulated by local and industrial demand (Emanuel et al., 2005).

Owing to its economic potential, S. birrea has been earmarked for crop development and improvement in southern Africa (Mollel and Goyvaerts, 2004). As industrial demand for its products is increasing, there is a growing concern about the sustainable supply (Nwonwu, 2006) and conservation of wild populations. Thus, in the quest for the domestication and improvement of $S$. birrea, understanding of seed germination of this plant is essential. Several members of Anacardiaceae, including Sclerocarya, are characterized by a drupe fruit with a stony endocarp. The endocarp of Sclerocarya and other related genera has a specialized structure, the operculum, through which the germinating embryo emerges (Von Teichman and Robbertse, 1986). Hills (1933) stated that the Anacardiaceae exhibits some remarkable seed protection mechanisms by means of a hard lignified endocarp and, intriguingly, the most ingenious devices to allow emergence of the germinating embryos. This ingenious opening device (operculum) represents one of the most sophisticated opening mechanisms in the germination of seeds (Von Teichman and Robbertse, 1986). Typical of the Anacardiaceae, the germinating unit (seed) in S. birrea is the true seed plus endocarp (Gaméné et al., 2004; Li et al., 1999).

Although considerable research has been undertaken on this species, there is still a dearth of knowledge on some aspects of its seed biology. Gaméné et al. (2004) inconclusively suggested that seed after-ripening, a decrease in mechanical resistance of the operculum after storage, or a combination of both factors can improve germination of $S$. birrea seeds. Another research gap relates to the effect of light on the germination process (Von Teichman et al., 1986). Generally, under natural conditions, temperature, light, water, oxygen, and mechanical pressures are some of the important factors that can influence seed germination of species like $S$. birrea. The purpose of this study was to identify the possible environmental and mechanical cues influencing the germination of $S$. birrea seeds.

\section{Materials and Methods}

Seed collection. Fruits of Sclerocarya birrea were collected in Feb. 2007 from the Mpumalanga Province of South Africa. Fruits were depulped and cleaned as described in the seed leaflet of the Danida Forest Seed Centre (2003). The seeds (endocarps) were separated from the pulp, washed, dried, and stored in brown paper bags at room temperature $\left(22 \pm 2{ }^{\circ} \mathrm{C}\right)$ for 4 weeks before being tested for germination ability. Seeds used to determine the initial moisture content were not stored.

Seed germination. Before each germination test, seeds were surface-decontaminated by soaking for $15 \mathrm{~min}$ in $0.5 \%(\mathrm{w} / \mathrm{v})$ solution of mercuric chloride $\left(\mathrm{HgCl}_{2}\right)$. Subsequently, seeds were thoroughly rinsed under tap and then distilled water. Before the germination experiments, seeds were soaked for $24 \mathrm{~h}$ in the dark at room temperature $\left(22 \pm 2{ }^{\circ} \mathrm{C}\right)$ in distilled water (covering $75 \%$ of the seed) for 
the hard endocarps to imbibe water. Seed germination was carried out on cotton wool moistened with distilled water and placed in plastic containers $(10.5 \times 10.5 \times 13.5 \mathrm{~cm})$ in growth chambers equipped with cool white fluorescent lamps (Osram L 58W/640, München, Germany) emitting a photosynthetic photon flux density $(P P F D)$ of $\approx 100$ $\mu \mathrm{mol} \cdot \mathrm{m}^{-2} \cdot \mathrm{s}^{-1}$ over a wavelength band of 400 to $700 \mathrm{~nm}$. Light intensity was measured with a quantum radiation sensor (Model Skp 215; Skye Instruments Ltd., Llandrindod Wells, Powys, UK). Seeds were considered to have germinated when the radicle had emerged at least $2 \mathrm{~mm}$ (Bewley, 1997). Each treatment consisted of 25 seeds and was replicated four times. All the experiments were repeated twice. Germination was recorded daily. The seeds that were subjected to continuous dark conditions were examined under a "green safe light" (wavelength of $510 \mathrm{~nm}$ and PPFD of $0.2 \mu \mathrm{mol} \cdot \mathrm{m}^{-2} \cdot \mathrm{s}^{-1}$ ) in the dark (Kulkarni et al., 2006). Seeds that were not treated served as a control unless mentioned otherwise. Unless stated otherwise, the duration of germination experiments was $14 \mathrm{~d}$.
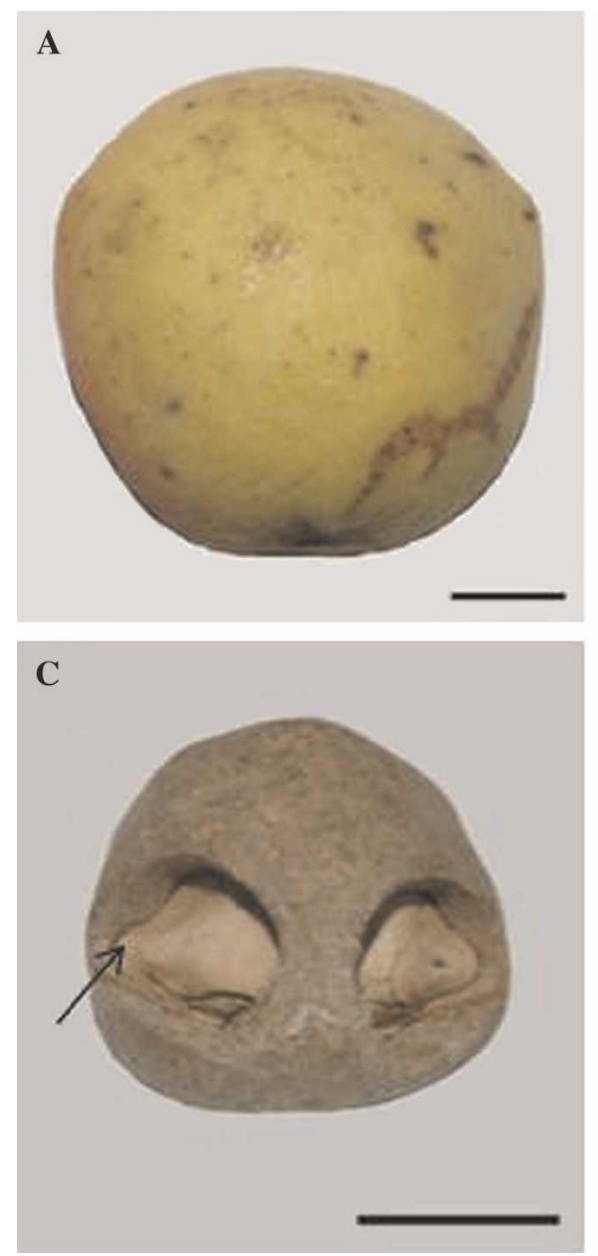

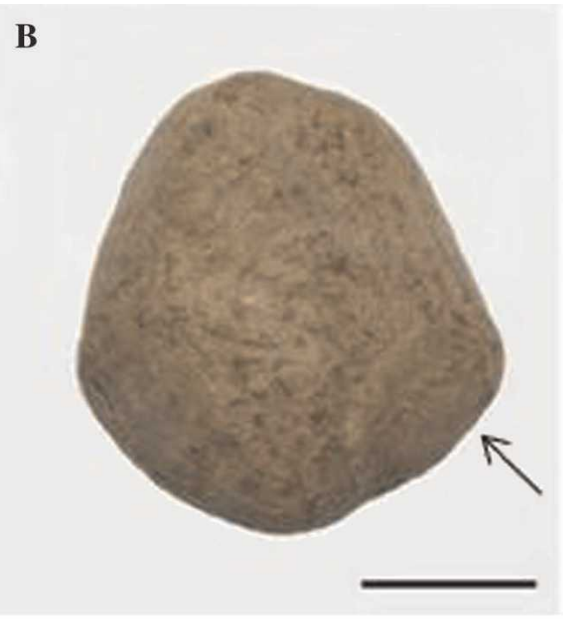

D

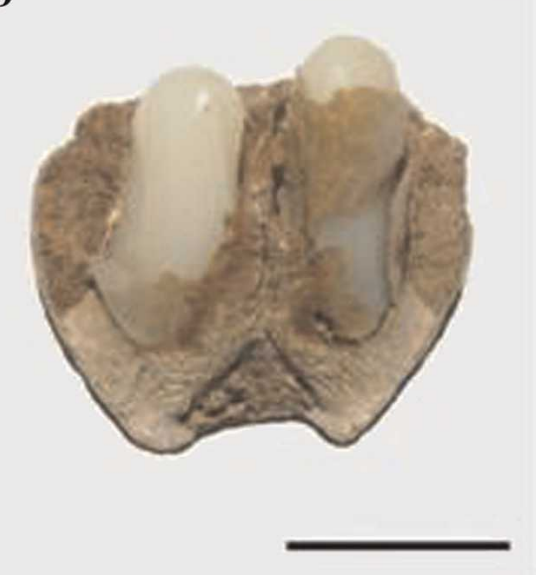

Fig. 1. Structure of a marula fruit, endocarp, and seed. (A) Ripe marula fruit. (B) An intact marula nut showing the hard lignified endocarp after removal of the fruit pulp. The weight of an intact marula endocarp after 12 months of storage at room temperature was $5.06 \pm 0.45 \mathrm{~g}(\mathrm{n}=100)$. The arrow indicates the operculum, a potential physical barrier to germination, through which the radicle emerges. The weight of an operculum was $0.195 \pm 0.025 \mathrm{~g}(\mathrm{n}=100)$. (C) An opercula-removed marula endocarp. The arrow indicates the position of the embryo. (D) Vertical section of a marula nut showing the walls of the stony endocarp and the true seeds. Scale bar $=10 \mathrm{~mm}$. 4-h intervals for $96 \mathrm{~h}$. Percentage water uptake was calculated on the basis of actual increase in seed mass over the initial seed mass (Hidayati et al., 2001):

$$
\% W_{\mathrm{s}}=\left[\left(W_{\mathrm{i}}-W_{\mathrm{d}}\right) / W_{\mathrm{d}}\right] \times 100
$$

where $W_{\mathrm{s}}=$ increase in mass of seeds; $W_{\mathrm{i}}=$ mass of seeds after a given interval of imbibition; and $W_{\mathrm{d}}=$ initial mass of seeds.

Effect of temperature. Intact seeds were soaked in distilled water for $24 \mathrm{~h}$ before exposing them to different temperatures. Seed germination was determined for both intact and opercula-removed seeds under alternating light (16-h photoperiod of 100 $\left.\mu \mathrm{mol} \cdot \mathrm{m}^{-2} \cdot \mathrm{s}^{-1}\right)$ and continuous dark conditions (containers were wrapped with aluminum foil). The seeds were incubated at constant temperatures of $10,15,20,25,30,35$, and 40 ${ }^{\circ} \mathrm{C}$ and alternating temperature of $30 / 15{ }^{\circ} \mathrm{C}$ $(14 \mathrm{~h} / 10 \mathrm{~h})$ in plant growth chambers (Controlled Environments Ltd., Manitoba, Canada). The optimum temperature for germination was determined on the basis of constant temperatures using the formula (Kulkarni et al., 2006):

$$
T_{\mathrm{o}}=\sum t p / \sum p
$$

where $T_{o}$ is the optimum temperature for germination and $p$ is the percentage germination at temperature $t$.

Effect of seed after-ripening on germination. Intact seeds with a moisture content of $11.1 \pm$ $1.6 \%$ (fresh weight basis) were stored in closed brown paper bags for 6,9 , and 12 months in the dark at room temperature $(22 \pm$ $2{ }^{\circ} \mathrm{C}$ ) after which germination was evaluated. After 6, 9, and 12 months, seeds were removed from storage and tested for their germination response to temperature and light. For cold and warm stratification experiments, only seed stored for 12 months was tested for germination.

Effect of irradiance intensity. Opercularemoved seeds were soaked in distilled water for $24 \mathrm{~h}$ as described earlier. Seeds were then exposed to continuous PPFD of 0 (dark), 20, and $115 \mu \mathrm{mol} \cdot \mathrm{m}^{-2} \cdot \mathrm{s}^{-1}$ under cool white fluorescent lamps and incubated at a temperature of $25 \pm 2^{\circ} \mathrm{C}$.

To examine the effect of different light spectra, seeds were placed in boxes fitted with red $\left(1.5 \mu \mathrm{mol} \cdot \mathrm{m}^{-2} \cdot \mathrm{s}^{-1}\right)$, far-red $(1.4$ $\left.\mu \mathrm{mol} \cdot \mathrm{m}^{-2} \cdot \mathrm{s}^{-1}\right)$, blue $\left(0.2 \mu \mathrm{mol} \cdot \mathrm{m}^{-2} \cdot \mathrm{s}^{-1}\right)$, and green $\left(0.2 \mu \mathrm{mol} \cdot \mathrm{m}^{-2} \cdot \mathrm{s}^{-1}\right)$ light filters and incubated under continuous light (100 $\left.\mu \mathrm{mol} \cdot \mathrm{m}^{-2} \cdot \mathrm{s}^{-1}\right)$ using cool white fluorescent lamps (Osram L 58W/640) at $25 \pm 2{ }^{\circ} \mathrm{C}$ (Kulkarni et al., 2006). Incubation in the dark served as the control. Percentage germination was recorded after $7 \mathrm{~d}$.

Pregermination treatments. Intact seeds were used for all the pregermination treatments. For all pregermination experiments, controls consisted of untreated seeds. Seeds were incubated on cotton wool moistened with distilled water. For the acid scarification treatment, seeds were soaked in $96 \%(\mathrm{v} / \mathrm{v})$ sulfuric acid $\left(\mathrm{H}_{2} \mathrm{SO}_{4}\right)$ for $2,4,6,8$, and $10 \mathrm{~h}$. 
Subsequently, the seeds were rinsed thoroughly in water for $30 \mathrm{~min}$. In another treatment, the seeds were subjected to boiling water for $5,10,15,20,25$, and $30 \mathrm{~min}$; removed; and left to cool for $30 \mathrm{~min}$. For the dry heat treatment, seeds were placed in the oven and exposed to $110^{\circ} \mathrm{C}$ for $2,4,6,8$, and $10 \mathrm{~h}$. For soaking treatments, seeds were placed in distilled water for $12,24,48,72$, 96 , and $168 \mathrm{~h}$ at ambient room temperature in the dark. After each treatment, the seeds were soaked in distilled water for $24 \mathrm{~h}$ (excluding soaking treatments) and incubated in a growth chamber (Conviron; Controlled Environments Ltd.) under continuous dark conditions at $25 \pm 2{ }^{\circ} \mathrm{C}$. Kinetin, gibberellic acid, and potassium nitrate $\left(\mathrm{KNO}_{3}\right)$ were tested at $0.1,0.01$, and $0.001 \mu \mathrm{M}$ concentrations under both continuous light and continuous dark conditions. Seeds were soaked in these solutions for $24 \mathrm{~h}$ and incubated on cotton wool moistened with distilled water at $25 \pm 2{ }^{\circ} \mathrm{C}$.

Seed stratification. Intact seeds were placed between two layers of paper towel, moistened with distilled water (using a 500$\mathrm{mL}$ plastic spray bottle), and kept inside plastic bags. These bags were then stored in the dark at $5{ }^{\circ} \mathrm{C}$ (cold stratification) and $40{ }^{\circ} \mathrm{C}$ (warm stratification) for 7, 14, 21, and $28 \mathrm{~d}$. For each treatment, four plastic bags were incubated at the respective temperature. After the respective incubation periods, germination tests were conducted under continuous dark conditions at $25 \pm 2{ }^{\circ} \mathrm{C}$. The seeds used for the stratification experiments were 12 months old.

Statistical analysis. Seed germination data were expressed as mean values \pm SE. The germination percentage data were arcsine-transformed before statistical analysis to ensure homogeneity of variance. One-way analysis of variance was conducted and Tukey's test was used to separate differences among treatment means. Data were analyzed using SPSS Version 15 (SPSS $^{\circledR}$, Chicago, IL).

\section{Results}

Seed moisture content. Sclerocarya birrea seed stored for 12 months at room tempera-

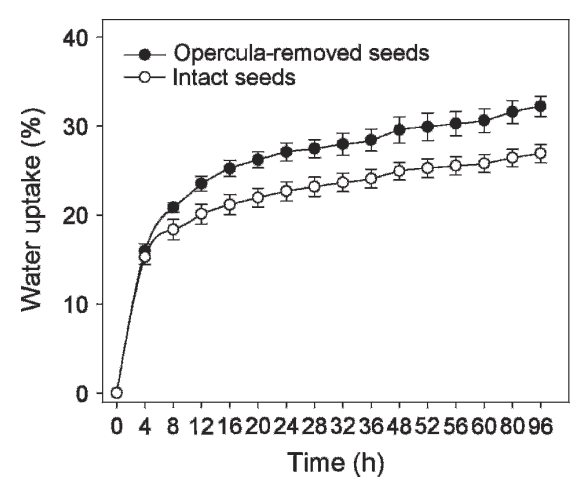

Fig. 2. Water uptake for Sclerocarya birrea subsp. caffra seeds during $96 \mathrm{~h}$ of incubation under alternating light (16-h photoperiod) at a room temperature of $22 \pm 2{ }^{\circ} \mathrm{C}(\mathrm{n}=25)$. ture had a mean fresh weight of $5.06 \pm 0.45$ $\mathrm{mg}(\mathrm{n}=100)$. The moisture percentage of excised true seeds from fresh nuts was $11.1 \pm$ $1.6 \%$, which was significantly higher than that of 12 -month-old nuts $(4.9 \pm 0.57 \%)$. The reduction in seed water content was achieved after $48 \mathrm{~h}$ at $110^{\circ} \mathrm{C}$.

Imbibition. Water uptake by both $12-$ month-old intact $(26.9 \pm 1.03 \%)$ and opercula-removed $(32.2 \pm 1.16 \%)$ seeds followed a similar imbibition curve, although water uptake for intact seeds was slightly lower (Fig. 2). Initially, in both intact and opercularemoved $S$. birrea seeds, the rate of water uptake up to $8 \mathrm{~h}$ was rapid and slowed down thereafter.

Effect of temperature and light on germination. At all the temperatures tested, alternating light (16-h photoperiod) was inhibitory for seed germination of 9-month-old opercula-removed seeds. Opercula-removed seeds exhibited higher percentage germination than intact seeds between 20 and $35{ }^{\circ} \mathrm{C}$ under constant dark conditions (Table 1). Low temperatures $\left(10\right.$ and $\left.15^{\circ} \mathrm{C}\right)$ inhibited seed germination of both intact and opercularemoved fruits. At high constant temperature regimes $\left(25\right.$ to $\left.40{ }^{\circ} \mathrm{C}\right)$, 12-month-old intact seeds resulted in better germination than 9month-old intact seeds. A similar trend was noted for alternating temperature $\left(30 / 15{ }^{\circ} \mathrm{C}\right)$ (Table 1).

After 6 months of storage, percentage germination of opercula-removed seeds was significantly higher under continuous dark in comparison with both continuous and alternating light conditions in which no germination was recorded (Fig. 3A). However, the inhibitory effect of white light was significantly reduced after 12 months of seed storage, exhibiting $65.2 \pm 0.9 \%$ and $67.2 \pm$ $1.3 \%$ germination under continuous and alternating light conditions, respectively (Fig. 3B). Intact seeds stored for up to 9 months did not germinate (data not shown), but after 12 months of storage, the seeds germinated equally in continuous dark $(31.3 \pm$ $4.4 \%)$, continuous light $(32.7 \pm 2.6 \%)$, and alternating light $(30.5 \pm 3.8 \%)$ conditions (Fig. 3C). For the same storage period, percentage germination of opercula-removed seeds showed no significant difference at $P P F D$ ranging from 0 to $115 \mu \mathrm{mol} \cdot \mathrm{m}^{-2} \cdot \mathrm{s}^{-1}$ (Table 2).

Table 1. Effect of different temperatures on Sclerocarya birrea susp. caffra seed germination under constant dark conditions at $25 \pm 2{ }^{\circ} \mathrm{C}$.

\begin{tabular}{|c|c|c|c|c|}
\hline \multirow{3}{*}{$\begin{array}{l}\text { Temperature } \\
\left({ }^{\circ} \mathrm{C}\right)\end{array}$} & \multicolumn{4}{|c|}{ Germination (\%) } \\
\hline & \multicolumn{2}{|c|}{ 9-month-old seeds } & \multicolumn{2}{|c|}{ 12-month-old seeds } \\
\hline & Opercula-removed & Intact & Opercula-removed & Intact \\
\hline 10 & $0 \pm 0 \mathrm{c}$ & $0 \pm 0 \mathrm{a}$ & $0 \pm 0 \mathrm{c}$ & $0 \pm 0 \mathrm{c}$ \\
\hline 15 & $0 \pm 0 \mathrm{c}$ & $0 \pm 0 \mathrm{a}$ & $0 \pm 0 \mathrm{c}$ & $0 \pm 0 \mathrm{c}$ \\
\hline 20 & $52.6 \pm 6.8 \mathrm{~b}$ & $0 \pm 0 \mathrm{a}$ & $54.5 \pm 4.3 \mathrm{~b}$ & $6.2 \pm 4.0 \mathrm{bc}$ \\
\hline 25 & $91.3 \pm 1.5 \mathrm{a}$ & $0 \pm 0 \mathrm{a}$ & $94.8 \pm 1.2 \mathrm{a}$ & $20.8 \pm 5.3 \mathrm{ab}$ \\
\hline 30 & $87.0 \pm 2.9 \mathrm{a}$ & $0 \pm 0 \mathrm{a}$ & $90.6 \pm 1.8 \mathrm{a}$ & $33.2 \pm 5.9 \mathrm{a}$ \\
\hline 35 & $87.0 \pm 6.4 \mathrm{a}$ & $0 \pm 0 \mathrm{a}$ & $86.2 \pm 5.8 \mathrm{a}$ & $20.8 \pm 7.9 \mathrm{ab}$ \\
\hline 40 & $25.0 \pm 5.9 \mathrm{bc}$ & $0 \pm 0 \mathrm{a}$ & $26.2 \pm 6.1 b c$ & $31.2 \pm 8.5 \mathrm{ab}$ \\
\hline $30 / 15$ & $86.4 \pm 5.1 \mathrm{a}$ & $0 \pm 0 \mathrm{a}$ & $92.4 \pm 4.2 \mathrm{a}$ & $18.0 \pm 3.4 \mathrm{ab}$ \\
\hline
\end{tabular}

Values $( \pm \mathrm{SE})$ with different letters in a column are significantly different at $5 \%$ level of significance according to Tukey's test $(P<0.05)$.
Opercula-removed seeds that did not germinate under a 16 -h photoperiod at a temperature of $25^{\circ} \mathrm{C}$ were moved to continuous dark conditions at $25{ }^{\circ} \mathrm{C}$ resulting in the reversal of the photoinhibition effect (Fig. 4). Similarly, 9-month-old seeds that did not germinate at 10,15 , and $20{ }^{\circ} \mathrm{C}$ showed significantly high germination percentages when shifted to $25^{\circ} \mathrm{C}$ in the dark (Fig. 4).

Red and blue light spectra had a stimulatory effect on the germination of 6-month-old opercula-removed seeds (Table 3). However, the sensitivity of opercula-removed seeds to different light spectra was reduced after prolonged seed storage of 12 months (Table 3).

Effect of after-ripening on germination. Intact seeds of $S$. birrea germinated to 33.2 $\pm 5.9 \%$ at $30{ }^{\circ} \mathrm{C}$ under constant dark conditions after a 12-month after-ripening period (Table 1). White light inhibited germination of 6-month-old opercula-removed seeds under both continuous and alternating light conditions. However, dark conditions promoted germination of $S$. birrea irrespective of the after-ripening period of the seeds (Figs. 3A-B). After 12 months of seed storage, the photoinhibition effect was partially lost with significant improvement in final germination (Fig. 3B).

Effect of pregermination treatments. All pregermination experiments were conducted on 12-month-old seed. Scarification with sulfuric acid $\left(\mathrm{H}_{2} \mathrm{SO}_{4}\right)$ did not improve germination of $S$. birrea seed relative to the control (data not shown). Boiling water and dry heat also did not improve seed germination of $S$. birrea in comparison with the controls. The germination for dry heat and boiling water treatments was $0 \%$ indicating that the seeds probably were killed. Furthermore, neither prolonged soaking $(P>0.420)$ nor application of plant growth regulators $(P>0.665)$ and $\mathrm{KNO}_{3}(P>0.882)$ were effective in enhancing germination of $S$. birrea seeds.

Cold stratification. The seeds of $S$. birrea subjected to cold stratification for a period of $14 \mathrm{~d}$ at $5{ }^{\circ} \mathrm{C}$ showed significantly greater germination $(65 \%)$ compared with nonstratified $(32 \%)$ and seeds that were cold-stratified for 7, 21, and $28 \mathrm{~d}$ (less than 32\%) (Fig. 5). Warm stratification did not improve seed germination $(P>0.348)$. 


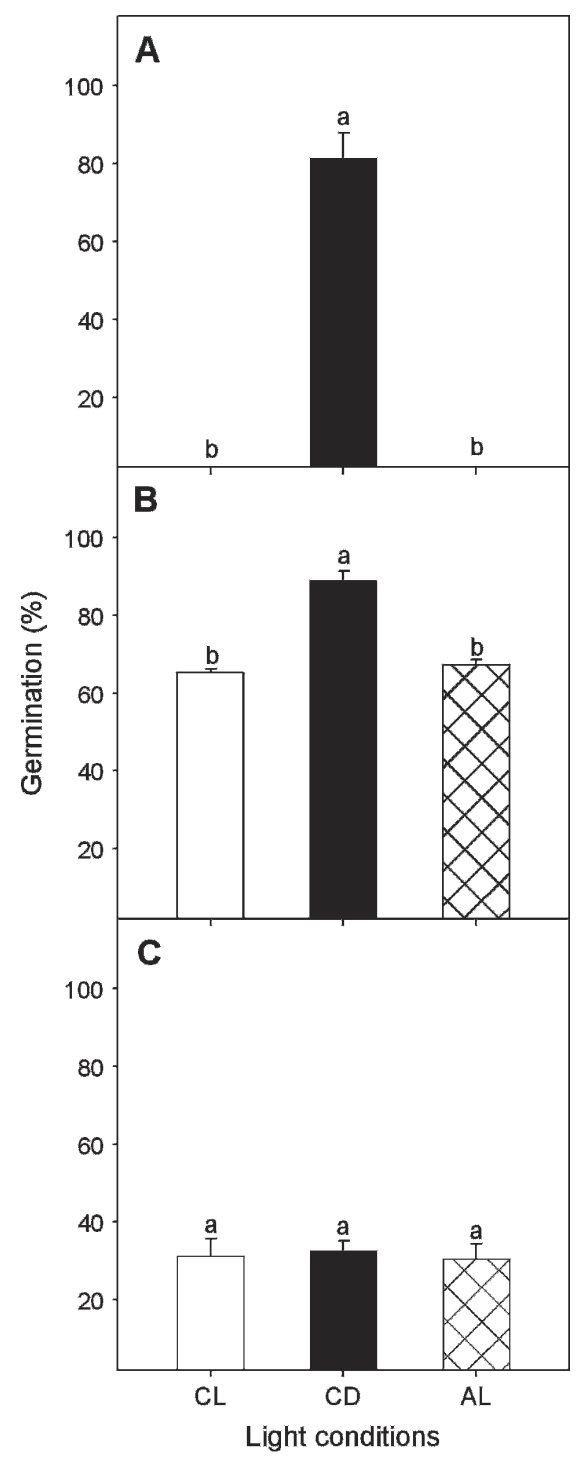

Fig. 3. Effect of different light conditions and seed storage on percentage germination of Sclerocarya birrea subsp. caffra seeds incubated at $25 \pm 2{ }^{\circ} \mathrm{C}$. $\mathrm{CL}=$ continuous light; $\mathrm{CD}=$ continuous dark; and $\mathrm{AL}=$ alternating light (16-h photoperiod). Seeds were soaked in distilled water for $24 \mathrm{~h}$ before germination tests. (A) Germination of opercula-removed seeds after a 6-month storage period. (B) Germination of 12-month-old opercularemoved seeds. (C) Germination of intact seeds after a 12-month storage period. The opercula were removed just before the germination tests. Six-month-old intact seeds did not germinate at all light conditions tested. Bars $( \pm \mathrm{SE})$ with similar letters are not significantly different at $5 \%$ level of significance according to Tukey's test $(P<0.05)$.

\section{Discussion}

Seed storage under dark conditions at room temperature for 12 months resulted in moisture loss from the seed. The difference in seed moisture content between fresh and 12-month-old seeds could explain the higher germination percentage after the prolonged storage period. On the basis of its tolerance to low moisture content of $4.9 \pm 0.57 \%, S$

Table 2. Effect of irradiance intensity on percentage germination of Sclerocarya birrea subsp. caffra seeds at $25 \pm 2{ }^{\circ} \mathrm{C}$.

\begin{tabular}{lccc}
\hline & \multicolumn{3}{c}{ Light intensity $\left(\mu \mathrm{mol} \cdot \mathrm{m}^{-2} \cdot \mathrm{s}^{-1}\right)$} \\
\cline { 2 - 4 } Storage period (months) & 0 & 20 & $0 \pm 0 \mathrm{~b}$ \\
\hline 6 & $80.9 \pm 5.3 \mathrm{~b}$ & $0 \pm 0 \mathrm{~b}$ & $0 \pm 0 \mathrm{~b}$ \\
9 & $91.3 \pm 1.5 \mathrm{a}$ & $0 \pm 0 \mathrm{~b}$ & $0.4 \pm 3.7 \mathrm{a}$ \\
\hline
\end{tabular}

Values ( \pm SE) with different letters in a column are significantly different at $5 \%$ level of significance according to Tukey's test $(P<0.05)$.

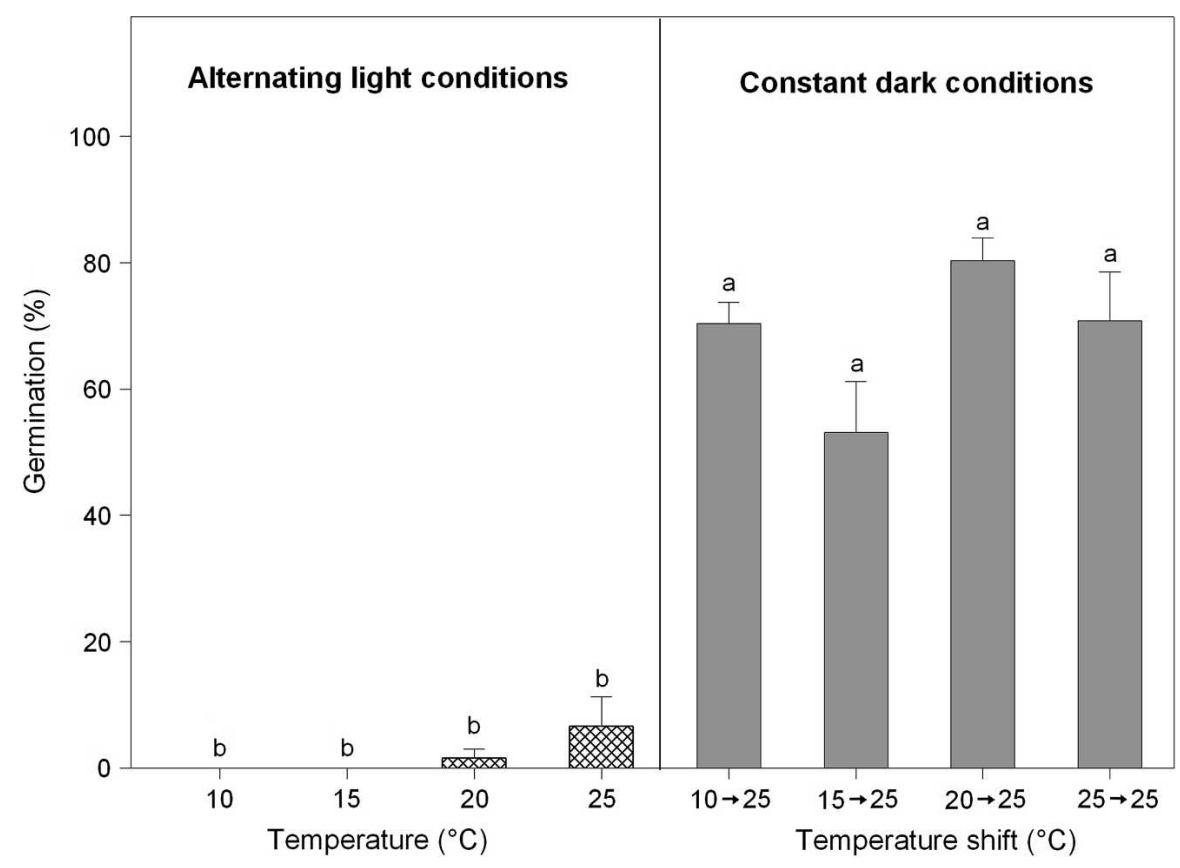

Fig. 4. Effect of temperature and light shifts on percentage germination of Sclerocarya birrea subsp. caffra seeds after a storage period of 9 months. The seeds that had been after-ripened for 9 months were shifted from alternating light to constant dark conditions after $14 \mathrm{~d}$. The graph shows that the inhibitory light effect is reversible. Bars ( \pm SE) with similar letters are not significantly different at $5 \%$ level of significance according to Tukey's test $(P<0.05)$.

birrea seeds can be classified as orthodox. This confirms the findings of Pritchard et al. (2004). According to Pritchard et al. (2004) and Tweddle et al. (2003), desiccation-tolerant or orthodox seeds can tolerate low moisture content below $7 \%$ and subsequently rehydrate without significant variation in viability. Generally, trees and shrubs adapted to arid and highly seasonal environments are overwhelmingly desiccation-tolerant (Tweddle et al., 2003).

The large seed of $S$. birrea exhibited typical characteristics of species found in dry tropical regions, where seeds have relatively large amounts of nutrients, to support rapid growth of seedlings, thereby increasing their chances of survival (Tweddle et al., 2003). Both intact and opercula-removed $S$. birrea endocarps readily imbibe water (Fig. 2). Similarly, intact Lannea microcarpa (Anacardiaceae) seeds imbibed water, although the rate of water uptake was faster for scarified endocarps (Neya et al., 2008). In contrast, the seeds of other species of Anacardiaceae such as Rhus aromatica and $R$. glabra were not permeable to water, even when their outer two layers (brachysclereids
Table 3. Effect of different light spectra on Sclerocarya birrea subsp. caffra seed germination at $25 \pm 2{ }^{\circ} \mathrm{C} .{ }^{z}$

\begin{tabular}{lcc}
\hline & \multicolumn{2}{c}{ Germination (\%) } \\
\cline { 2 - 3 } Light source & $\begin{array}{c}\text { 6-month-old } \\
\text { seeds }\end{array}$ & $\begin{array}{c}\text { 12-month-old } \\
\text { seeds }\end{array}$ \\
\hline White light & $0 \mathrm{~d}$ & $79.1 \pm 4.1 \mathrm{a}$ \\
Dark & $81.3 \pm 6.5 \mathrm{a}$ & $83.3 \pm 0.0 \mathrm{a}$ \\
Red & $53.2 \pm 7.5 \mathrm{ab}$ & $80.5 \pm 8.6 \mathrm{a}$ \\
Far-red & $32.8 \pm 12.1 \mathrm{bc}$ & $61.1 \pm 6.3 \mathrm{~b}$ \\
Green & $24.7 \pm 5.1 \mathrm{c}$ & $61.1 \pm 2.4 \mathrm{~b}$ \\
Blue & $46.6 \pm 17.8 \mathrm{~b}$ & $77.7 \pm 2.4 \mathrm{a}$ \\
\hline
\end{tabular}

${ }^{\mathrm{z}}$ Opercula-removed seeds were soaked in distilled water for $24 \mathrm{~h}$ before germination test. Values $( \pm \mathrm{SE})$ with different letters in a column are significantly different at $5 \%$ level of significance according to Tukey's test $(P<0.05)$.

and osteosclereids) were removed (Li et al., 1999).

Because $S$. birrea is adapted to the drier tropical regions, high temperatures in the range of 25 to $35^{\circ} \mathrm{C}$ favors seed germination. In this study, the calculated optimum temperature $\left(T_{o}\right)$ for the germination of $S$. birrea seeds was $29{ }^{\circ} \mathrm{C}$ under constant dark conditions. Figure 4 shows the effect of both light 


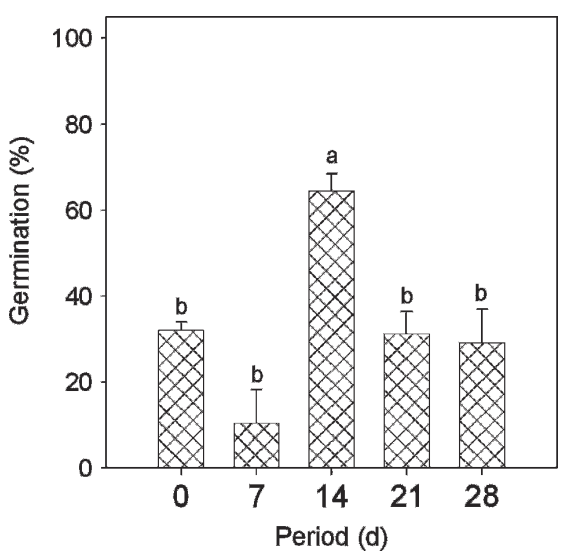

Fig. 5. Effect of cold stratification $\left(5{ }^{\circ} \mathrm{C}\right)$ on germination of intact Sclerocarya birrea subsp. caffra under continuous dark conditions at $25 \pm$ $2{ }^{\circ} \mathrm{C}$. The seeds were cold-stratified after a 12-month storage period. Bars ( $\pm \mathrm{SE})$ with similar letters are not significantly different at $5 \%$ level of significance according to Tukey's test $(P<0.05)$.

and temperature shifts for S. birrea seeds after 9 months storage. When opercularemoved seeds did not germinate at 10 and $15^{\circ} \mathrm{C}$ or showed little germination at 20 and $25{ }^{\circ} \mathrm{C}$ under a 16 -h photoperiod, they were shifted to continuous dark at $25{ }^{\circ} \mathrm{C}$, which significantly increased percentage germination. Continuous exposure of seeds to specific light spectra had a significant influence on percentage germination of 6-month-old seeds of S. birrea (Table 3). In particular, red and blue light increased seed germination as compared with white light for the 6-monthold seed. These results may indicate the influence of phytochrome family of photoreceptors on seed germination. The inhibitory effect of white light may be the result of a high rate of interconversion between the $\mathrm{P}_{\mathrm{fr}}$ and $\mathrm{P}_{\mathrm{r}}$ forms of phytochrome caused by high PPFD of light of any wavelength (Ellis et al., 1989). This high irradiance reaction overrides the reversible phytochrome reactions and may be inhibitory to seed germination (Baskin and Baskin, 1998). The stimulatory influence of both red and blue light observed for 6-month-old seed was lost with prolonged storage of seeds (12 months) at room temperature (Table 3 ).

Another factor influencing seed germination is after-ripening in storage. Von Teichman et al. (1986) and Gaméné et al. (2004) reported that final germination of $S$. birrea seeds increased after 1 year and 6 months of storage under ambient temperature and relative humidity conditions, respectively. This shows that after-ripening of seeds during storage at ambient temperatures is critical for germination of $S$. birrea. Using opercularemoved seeds, Pritchard et al. (2004) showed that physiological rather than physical dormancy had a predominant influence on seed germination of $S$. birrea. For $L$. microcarpa, the increase in germination with drying was attributed to seed after-ripening and/or a loss of physiological dormancy (Neya et al., 2008). It is further suggested that desiccation tolerance is greatest for seeds exhibiting physical and combinational (physical and physiological) dormancy (Tweddle et al., 2003).

Intact seeds of $S$. birrea stored up to 6 months failed to germinate under all the light conditions (continuous light, continuous dark, and alternating light) examined. However, after 12 months of storage, there was a partial loss of dormancy (Fig. 3C). Similarly, for Prosopis juliflora, storage of seeds significantly achieved greater and faster germination (El-Keblawy and Al-Rawai, 2006). The germination response of $S$. birrea seeds to light and storage suggests both physiological and endocarp-imposed dormancy.

Von Teichman et al. (1986) showed that acid scarification was not effective in enhancing seed germination of $S$. birrea. However, Gaméné et al. (2004) reported an increase in germination after treating the seeds with hydrochloric acid (HCI). Li et al. (1999) have reported that concentrated $\mathrm{H}_{2} \mathrm{SO}_{4}$ released seed dormancy of $R$. aromatica, and boiling water that of $R$. glabra, both members of Anacardiaceae. For $S$. birrea scarification with $\mathrm{H}_{2} \mathrm{SO}_{4}$, boiling water, dry heat, and prolonged soaking of seeds did not improve germination.

Seeds of some species with stony endocarps germinate better when they are subjected to different periods of cold stratification, e.g., Cornus (90 to 120 d), Coryllus (60 to $180 \mathrm{~d})$, Menispermum (14 to $28 \mathrm{~d}$ ), Morus (30 to 90 d), Nyssa (30 to 120 d), and Oemleria (120 d) (Young and Young, 1992). For $S$. birrea seeds, a cold stratification treatment of $14 \mathrm{~d}$ significantly increased germination (Fig. 5). The response to cold stratification indicates adaptive mechanisms and significance of natural environmental cues such as low winter temperatures to which $S$. birrea seeds may get exposed before germination.

\section{Conclusions}

This study has identified the factors that influence the germination of $S$. birrea. Both intact and opercula-removed seeds readily imbibe water suggesting physiological rather than physical dormancy. Light had an inhibitory effect on opercula-removed seeds, which was subsequently eliminated after prolonged storage at ambient temperature. Seeds of $S$. birrea can be considered orthodox because they tolerated desiccation. The highest germination was recorded under constant dark conditions at $25{ }^{\circ} \mathrm{C}$ for opercula-removed seeds exposed to an after-ripening period of 12 months. The findings of this study indicate that after-ripening, light, temperature, and cold stratification are critical determinants for the germination of $S$. birrea seeds.

\section{Literature Cited}

Baskin, C.C. and J.M. Baskin. 1998. Seeds: Ecology, biogeography, and evolution of dormancy and germination. Academic Press, London, UK. Bewley, J.D. 1997. Seed germination and dormancy. Plant Cell 9:1055-1066.
Danida Forest Seed Centre. 2003. Sclerocarya birrea (A. Rich.) Hochst. Seed leaflet no. 72, Denmark.

El-Keblawy, A. and A. Al-Rawai. 2006. Effects of seed maturation time and dry storage on light and temperature requirements during germination in invasive Prosopis juliflora. Flora 201:135-143.

Ellis, R.H., T.D. Hong, and E.H. Roberts. 1989. Quantal response of seed germination in seven genera of Cruciferae to white light of varying photon flux density and photoperiod. Ann. Bot. (Lond.) 63:145-158.

Eloff, J.N. 2001. Antibacterial activity of Marula (Sclerocarya birrea) (A. rich.) Hochst. subsp. caffra (Sond.) Kokwaro) (Anacardiaceae) bark and leaves. J. Ethnopharmacol. 76:305308.

Emanuel, P.L., C.M. Shackleton, and J.S. Baxter. 2005. Modelling the sustainable harvest of Sclerocarya birrea subsp. caffra fruits in the South African lowveld. For. Ecol. Mgt. 214:91-103.

Gaméné, C.S., D. Erdey, D. Baxter, N. Motete, and P. Berjak. 2004. Desiccation, germination and storage of Sclerocarya birrea seeds from Burkina Faso, p. 40-56. In: Sacandé, M., D. Jøker, M.E. Dulloo, and K.A. Thomsen (eds.). Comparative storage biology of tropical tree seeds. FLD-IPGRI, Rome, Italy.

Hidayati, S.N., J.M. Baskin, and C.C. Baskin 2001. Dormancy-breaking and germination requirements for seeds of Symphoricarpos orbiculatus (Caprifoliaceae). Amer. J. Bot. 88:1444-1451.

Hills, W.H. 1933. The method of germination of seeds enclosed in a stony endocarp. Ann. Bot. (Lond.) 47:873-887.

Jaenicke, H. and M.K. Thiong'o. 2000. Preliminary nutritional analysis of marula (Sclerocarya birrea) fruits from two Kenyan provenances. Acta Hort. 531:245-249.

Kleiman, R., D.A. Ashley, and J.H. Brown. 2008. Comparison of two seed oils used in cosmetics, moringa and marula. Ind. Crops Prod. 28:361364.

Kulkarni, M.G., S.G. Sparg, and J. Van Staden. 2006. Dark conditioning, cold stratification and a smoke-derived compound enhance the germination of Eucomis autumnalis subsp. autumnalis seeds. S. Afr. J. Bot. 72:157162.

Li, X., J.M. Baskin, and C.C. Baskin. 1999. Anatomy of two mechanisms of breaking physical dormancy by experimental treatments in seeds of two North American Rhus species (Anacardiaceae). Amer. J. Bot. 86: $1505-1511$.

Mojeremane, W. and S.O. Tshwenyane. 2004. The resource role of morula (Sclerocarya birrea): A multipurpose indigenous fruit tree of Botswana. J. Biol. Sci. 4:771-775.

Mollel, H.N. and E.M.A. Goyvaerts. 2004. Preliminary examination of factors affecting Agrobacterium tumefaciens-mediated transformation of marula, Sclerocarya birrea subsp. caffra (Anacardiaceae). Plant Cell Tissue Organ Cult. 79:321-328

Muok, B.O., A. Matsamura, T. Ishii, and D.W Odee. 2007. Genetic diversity within Sclerocarya birrea populations in Kenya. J. Arid Environ. 71:1-11

Neya, O., F.A. Hoekstra, and E.A. Golovina. 2008 Mechanism of endocarp-imposed constraints of germination of Lannea microcarpa seeds. Seed Sci. Res. 18:13-24.

Nwonwu, F.O.C. 2006. The socio-cultural and economic relevance of the Marula tree and its 
sustainable use in Africa. Afr. Insight 36:249265.

Pritchard, H.W., M.I. Daws, B.J. Fletcher, C.S Gaméné, H.P. Msanga, and W. Omondi. 2004. Ecological correlates of seed desiccation tolerance in tropical African dry land trees. Amer. J. Bot. 91:863-870.

Shackleton, S., B. Campbell, H. Lotz-Sisitka, and C. Shackleton. 2008. Links between the local trade in natural products, livelihoods and poverty alleviation in a semi-arid region of South Africa. World Dev. 36:505-526.
Tweddle, J.C., J.B. Dickie, C.C. Baskin, and J.M. Baskin. 2003. Ecological aspects of seed desiccation sensitivity. J. Ecol. 91:294304.

Von Teichman, I. and P.J. Robbertse. 1986. Development and structure of the drupe in Sclerocarya birrea (Richard) Hochst. subsp. caffra Kokwaro (Anacardiaceae), with special reference to the pericarp and the operculum. Bot. J. Linn. Soc. 92:303-322.

Von Teichman, I., J.G.C. Small, and P.J. Robbertse. 1986. A preliminary study on the germination of
Sclerocarya birrea subsp. caffra. S. Afr. J. Bot. 52:145-148.

Wynberg, R.P., S.A. Laird, S. Shackleton, M. Mander, C. Shackleton, P. Du Plessis, S. Den Adel, R.R.B. Leakey, A. Botelle, C. Lombard, C. Sullivan, T. Cunningham, and D. O'Regan. 2003. Marula policy brief: Marula commercialization for sustainable and equitable livelihoods. For. Trees Livelih. 13:203-215.

Young, J.A. and C.G. Young. 1992. Seeds of woody plants in North America. Dioscorides Press, Portland, OR. 